\title{
Cockleshell Structure under Low-Velocity Impact
}

\author{
Nurhamizah Anuar, Kamarul-Azhar Kamarudin ${ }^{1}$, Mohamed Nasrul Mohamed Hatta, \\ Nurul Afiqah Abdul Wahid \\ ${ }^{1}$ Crashworthiness and Collision Research Group (COLORED), \\ Faculty of Mechanical and Manufacturing Engineering, Universiti Tun Hussein Onn Malaysia, \\ 86400 Batu Pahat, Johor, Malaysia \\ kamarula@uthm.edu.my ${ }^{1}$
}

\begin{abstract}
In recent years, there has been a trend to reuse the waste of cockleshell such as reinforcement in epoxy composites formation, with natural fibers due to their low cost, biodegradable, and recyclable. This paper describes the effect of a low-velocity impact test on the composite structure of a cockleshell. The mixture of cockleshell powder, water and sucrose leads to increased mechanical strength and composite biodegradability which is important for waste management and environmental conservation. This study purposely to determine the mechanical behavior of cockleshell reinforced composite panel under low-velocity impact and also to characterize the damage behavior of a cockleshell. The cockleshell was crushed and milled into small size at around $160 \mu \mathrm{m}$ to $200 \mu \mathrm{m}$. The mechanical behavior was defined by using Hydroshot machine at the velocity of $1 \mathrm{~m} / \mathrm{s}$. The result shows that 10D (10\% of sucrose with a double layer) has the highest impact force which is $54 \mathrm{~N}$. While sample 30D (30\% of sucrose with a double layer) has the highest value of energy absorption with value of $0.491 \mathrm{~J}$. Generally, the result shows that double layer has a better value than single layer in terms of force and energy value because of thickness as an important factor in determining the impact response and apparently, the thickest has a great absorption.
\end{abstract}

Key words: Cockleshell, double layer, Hydroshot machine, low-velocity impact.

\section{INTRODUCTION}

Aquaculture is one of the main sectors in Malaysia because the availability of protein easily obtained from the sea. The cockleshell is one of the abundant sources of protein obtainable from the sea. During the year 2014, the annual production of cockleshell about 1,301,644 $\mathrm{kg}$ with the worth of RM 970,780 [1]. However, the development of cockleshell industry indicates that the waste would rise as well. The waste and dumped irresponsibility of cockleshell produce hostile odour by the time and disturbing the surrounding. One of the solutions to minimize the unsustainable number of raw cockleshells is to substitute them and blend with other material and produce a durable material in mechanical properties for another application[2]-[4] .
Calcium carbonate $\mathrm{CaCO}_{3}$ or also synonyms with limestone and chalk is a carbonic salt of calcium usually used in therapeutically and which also has potential biomass to many industry. As the past researcher's result, the calcium carbonate have found major mineral content in cockleshell [5]-[7]. Currently, the applications of cockleshell were concrete replacement or artificial reef [8],[9] bone repair [5], thermal gravimetric analysis [6] and many more. The physical of the cockleshell looks tough, and basically, it contains maximum $98 \%$ of calcium carbonate $\left(\mathrm{CaCO}_{3}\right)$ and biopolymer natural molecule [10] and also could be as biomaterial usage [11].

Composite material defines as a combining of two or more material which have different properties to form a unique properties of composition [10]. Natural composite can be found in animal and plants which every part have their own strength and weakness which is combined to form a much stronger material. Composite that has been created purposely improved the mechanical behaviour such as strength, durability, and high temperature. The concentration, size, shape, distribution, and orientation are the factors that influence the properties composites.

Low velocity impacts depend on energy transfer between the target and projectile. Projectile velocity relies on how energy dissipation and the distribution of damage will occur. Literally, most of composite material damaged internally due to low velocity, while residual stability and service life loss internally decreases in composite material. Low velocity $n$ range between 1 to $10 \mathrm{~m} / \mathrm{s}$ which depending on the mass of impactor and its target rigidity and lead to specified damage [12]. Most of the composite material damaged internally due to low velocity, while extra stability and service life loss internally decreases in composite material. Damage evolution due to impact was depends on loading speed as instance, the higher deformation speed, the deeper voids and dimples of a material [13].

Therefore, the aim of this study was to define the mechanical and damage behaviour of cockleshell structure as the dominant material with the presence of sucrose as a binder. In this study, the mixture of cockleshell separated into two 
categories, i.e. single layer and a double layer of the specimen at a specified sucrose ratio. The mechanical behaviour of composite material due to sudden impact test was done by using Hydroshot machine. This research could be an alternative way to familiarize cockleshell as a natural composite which can replace synthetic composite.

\section{MATERIAL PREPARATION}

To eliminate unpleasant smells and dirt, the cockleshell soaked with tapped water for several hours and dried under the sun to ensure that there is no moisture on the cockleshell. The cockle shell was crushed by using granulator machine until get granule size around $5 \mathrm{~mm}$. This process is vital before the crushed cockleshell turned into powder form using abrasion machine. In abrasion machine, the drum rotated for 1000 rotation for half an hour, and the size of the cockleshell is about $500 \mu \mathrm{m}$ to $5 \mathrm{~mm}$. Next, the cockleshell sieved by using a sieve shaker machine to produce fine powder around size 160 to $200 \mu \mathrm{m}$.

For material fabrication, all the material measured according to the certain ratio. In this study, $10 \%$ and $30 \%$ of sucrose composition was used while water fixed at $2 \%$ for each specimen and the rest was cockleshell powder. All the measured materials were mixed manually and then placed into the mould with dimension $100 \mathrm{~mm} \times 10 \mathrm{~mm} \times 6 \mathrm{~mm}$ by using a hydraulic press machine. The compaction process was used 8 tonnes of pressure with 10 minutes holding time. The compacted sample was dried at $150^{\circ} \mathrm{C}$ for an hour by using an oven.

In this study, Hydroshot machine was used for the impact test at below $1 \mathrm{~m} / \mathrm{s}$ [14], all the samples have been tested to define the impact force and energy absorption. The samples tested for different composition of sucrose, i.e. $10 \mathrm{wt} \%$ and $30 \mathrm{wt} \%$. Furthermore, the samples also undergo an impact test to be compared between single layer and double layer of sample to determine the mechanical and damaging behaviour. For Hydroshot machine, the applicable sample was $100 \mathrm{~mm} \times 100$ $\mathrm{mm} \times 1-3 \mathrm{~mm}$ whereas, in this study's sample was $100 \mathrm{~mm} x$ $10 \mathrm{~mm} \times 6 \mathrm{~mm}$. To avoid any problem occurred during an impact test, a sample holder has designed as shown in Figure 1. The sample holder functioned as to grip the sample during impact test conducted so that the strikers with load detector touch the centre of the sample accurately.

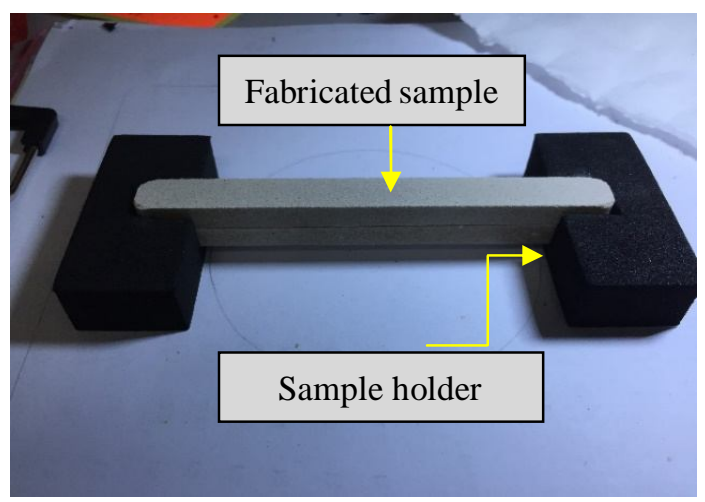

Figure 1: Sample holder

\section{RESULT AND DISCUSSION}

\subsection{Mechanical Behavior}

Impact test functioned in evaluating the ductile-to-brittle transition behavior of the material. Toughness is one of the mechanical concepts that used to determine the material's ability to absorb energy to fracture. From the result obtained, the value of force and energy absorption at different sucrose percentages identified. The samples type was categorized as $10 \%$ sucrose single layer $(10 \mathrm{~S}), 30 \%$ sucrose single layer (30S), $10 \%$ sucrose double layer (10D), and 30\% sucrose double layer (30D) according to the sucrose composition, respectively. Table 1 presents the categorized sample with energy and force value results obtained from the impact test experiment which have been calculated the average value from three samples.

Table 1: Categorized sample with energy and force value

\begin{tabular}{|c|c|c|c|}
\hline Description & $\begin{array}{c}\text { Sample } \\
\text { Type }\end{array}$ & $\begin{array}{c}\text { Ener } \\
\text { gy (J) }\end{array}$ & $\begin{array}{c}\text { Impact } \\
\text { force (N) }\end{array}$ \\
\hline $\begin{array}{c}\text { 10\% sucrose } \\
\text { (Single layer) }\end{array}$ & $10 \mathrm{~S}$ & 0.276 & 37 \\
\hline $\begin{array}{c}30 \% \text { sucrose } \\
\text { (Single layer) }\end{array}$ & $30 \mathrm{~S}$ & 0.388 & 23 \\
\hline $\begin{array}{c}\text { 10\% sucrose } \\
\text { (Double layer) }\end{array}$ & $10 \mathrm{D}$ & 0.295 & 54 \\
\hline $\begin{array}{c}30 \% \text { sucrose } \\
\text { (Double layer) }\end{array}$ & $30 \mathrm{D}$ & 0.491 & 40 \\
\hline
\end{tabular}

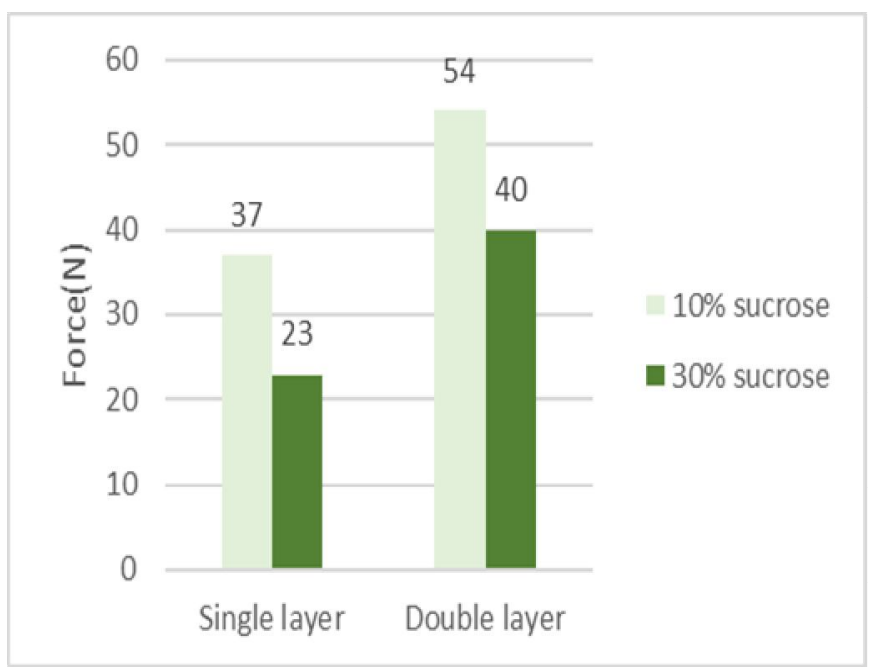

Figure 2: Impact force at different composition of sucrose Figure 2 presents the summary statistic for impact force where 10D was the highest with $29.3 \mathrm{~N}(35.06 \%)$ followed by $30 \mathrm{D}(25.97 \%), 10 \mathrm{~S}(24.03 \%)$ and the lowest is $30 \mathrm{~S}$ with value 
14.94\%, respectively. Approximately, double layer has significant value more than single layer with different composition of sucrose. For impact force, $10 \%$ of sucrose has better value compared to $30 \%$ of sucrose where some research has been stated that the concentration of sucrose influenced the value of force, wherein this study, sucrose as a binder that only needs a small amount [15].

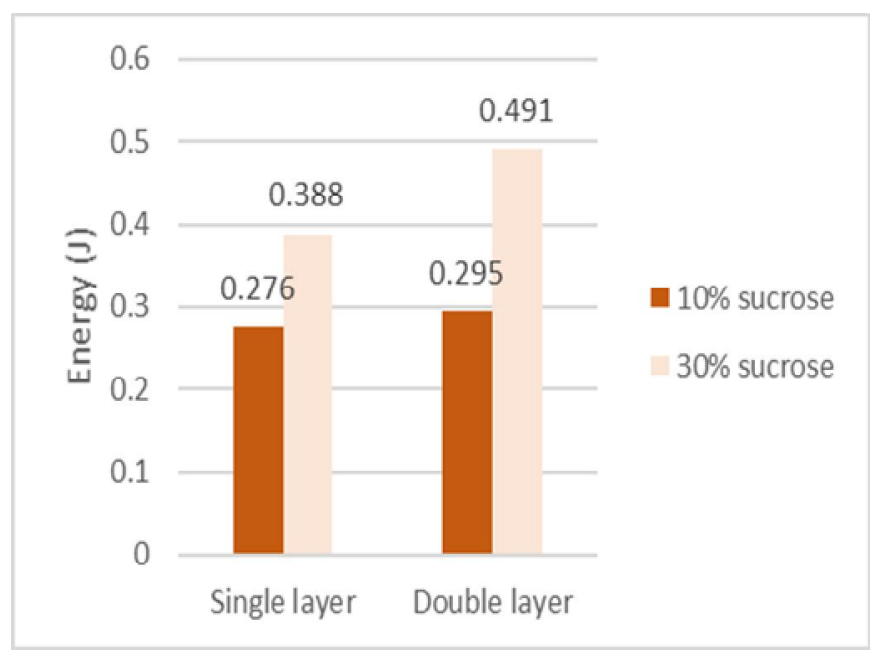

Figure 3: Average energy

From Figure 3, it can be observed that the energy value for the double layer reported significantly higher than single layer. Furthermore, the highest energy value represent 30D was about $0.491 \mathrm{~J}(33.86 \%)$ which has more than $30 \mathrm{~S}$ which is the value only $0.295 \mathrm{~J}(26.76 \%)$.

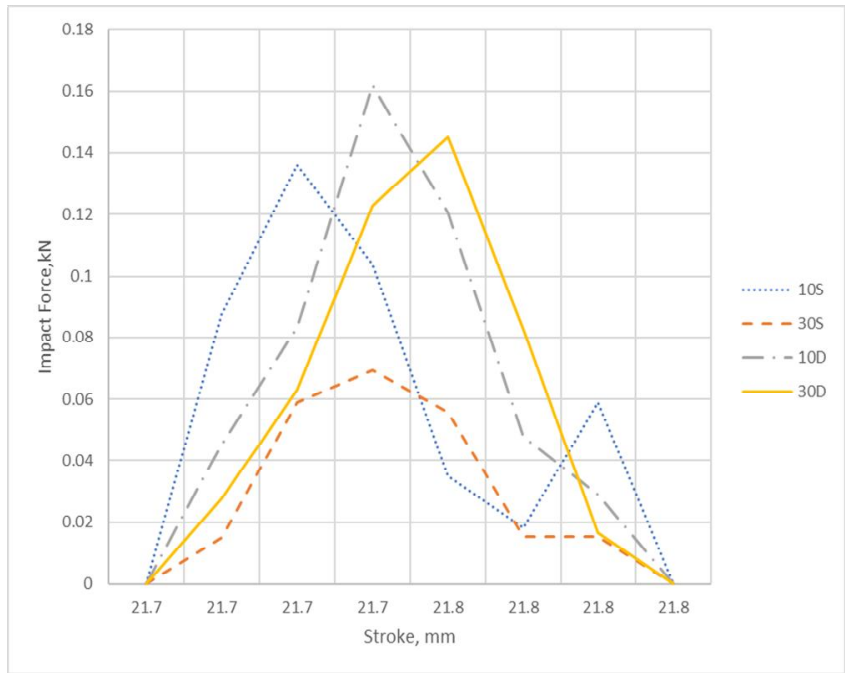

Figure 4: Force against stroke value

Thickness effect of composite structure on low-velocity impact testing has frequently studied since it recognized as an essential aspect in determining the impact response. Some scenario of under velocity impact, the thin composite works differently compared to the thick composite [16]. In this study, the layer represents the thickness of the target plates sample, which have a different value obtained between single layer and double layer. Referring to the Figure 4 represent average force against stroke, sample 10D shows the highest force reading followed by $30 \mathrm{D}, 10 \mathrm{~S}$ and $30 \mathrm{~S}$, respectively.

\subsection{Damage Behavior}

Previous study stated in the literature where usually low energy around 1 to $5 \mathrm{~J}$ has a minimum damage [17]-[19]. One of the failure in low-velocity impact is matrix cracking which caused by stress, compression and shearing parallel to the fiber which arises because of fiber-matrix mismatching as well as deboned between fibers and matrix [20],[21]. Studied by Joshi and Sun [22] evaluate the interaction between delamination-matrix crack for transverse-impact laminates and also cracks in matrix are well known as major matrix crack which leading to delamination.

Table 2 shows the damage failure of sample after impact test conducted. From the observation, clearly show that single layer fragment into three-part, i.e. at the center and end of both samples. Whereas, the double layer fragment into two pieces only where at the center of the sample because a single layer of sample is secured tightly with the sample holder and the impact load only focused on one layer.

Table 2: Damage failure of sample

\begin{tabular}{|c|c|c|}
\hline & $10 \%$ sucrose & $30 \%$ sucrose \\
\hline \multirow{2}{*}{$\begin{array}{c}\text { Single } \\
\text { layer }\end{array}$} & & \\
& & \\
\hline & & \\
\hline & & \\
\hline
\end{tabular}


The comparison was about the present study compared with previous research which conducted by Muhammad Iqbal [23] where the specimen tested by using two methods, i.e. Three-Point Bending and Charpy to get force and energy value meanwhile for present research by using Hydroshot machine. The average value taken for both studies and for present study, the comparison only considered the single layer. Table 3 compares the experimental data for present and past study in category of force and energy.

Table 3: Experimental data for present and past researcher

\begin{tabular}{|c|c|c|c|}
\hline \multicolumn{2}{|c|}{ Researcher } & Present & $\begin{array}{c}\text { Muhd Iqbal } \\
{[23]}\end{array}$ \\
\hline \multicolumn{2}{|c|}{ Method Test } & $\begin{array}{l}\text { Impact test } \\
\text { (Hydroshot }\end{array}$ & $\begin{array}{l}\text { Three-Point } \\
\text { Bending and }\end{array}$ \\
\hline \multirow{2}{*}{ Force } & $\begin{array}{c}10 \% \\
\text { sucrose }\end{array}$ & $37 \mathrm{~N}$ & $11.24 \mathrm{~N}$ \\
\hline & $\begin{array}{c}30 \% \\
\text { sucrose }\end{array}$ & $23 \mathrm{~N}$ & $20.15 \mathrm{~N}$ \\
\hline \multirow{2}{*}{ Energy } & $\begin{array}{l}10 \% \\
\text { sucrose }\end{array}$ & $0.276 \mathrm{~J}$ & $0.082 \mathrm{~J}$ \\
\hline & $\begin{array}{c}30 \% \\
\text { sucrose }\end{array}$ & $0.388 \mathrm{~J}$ & $0.102 \mathrm{~J}$ \\
\hline
\end{tabular}

Generally, the value of force and energy for present study is higher than the previous study Muhd Iqbal [23]. The force at $10 \%$ sucrose composition for the present study was $37 \mathrm{~N}$ compared to past study only has $11.24 \mathrm{~N}$. Whereas for $30 \%$ of sucrose, the present study has $23 \mathrm{~N}$ which slightly more than the past study with value $20.15 \mathrm{~N}$. Furthermore, energy value of $10 \%$ sucrose for present study was $0.276 \mathrm{~J}$, which also have more energy value than past study $0.082 \mathrm{~J}$. However, the different method of impact test might be a factor of a different value obtained.

\section{CONCLUSION}

The objectives of this study to determine the mechanical behavior of cockleshell reinforced composite panel under low-velocity impact and to characterize damage behavior of cockleshell was achieved. The major mineral content in cockleshell that is calcium carbonate was made them sturdy and more durable which the binder only needs a small amount. This can be shown in the result of impact force where $10 \%$ of sucrose composition was better than $30 \%$ of sucrose. Differently in energy value, $30 \%$ of sucrose has better than $10 \%$ of sucrose. Generally, the result shows that double layer has a better value than single layer because of thickness as an essential factor in determining the impact response and apparently, the thickest has a great absorption. For damage behaviour, matrix cracking is one of the form of failure that is normally affected by low-velocity impact and caused by stress, compression and shearing parallel to the fibers.

\section{ACKNOWLEDGEMENT}

The authors would like to acknowledge the support provided by Research Management Centre, UTHM under the Research Fund E15501. Credits were given to Universiti Tun Hussein Onn Malaysia (UTHM) for providing the equipment and facilities especially Faculty of Mechanical and Manufacturing Engineering (FKMP).

\section{REFERENCES}

[1] Lembaga Kemajuan Ikan Malaysia, "Laporan Risikan Pasaran Tahun 2014,” pp. 1-21, 2014.

[2] T. S. Babu, "Development of the Durability of Pervious Concrete by Using Crushed Seashells," vol. 7, no. 10, pp. 1-5, 2019.

[3] E. Mellanby, "An experimental investigation on rickets. 1919.," Nutrition, vol. 5, no. 2, pp. 81-86; discussion 87, 1989.

[4] G. Pandeeswari, G. R. Seenivasan, and V. Nandakumar, "Experimental Study on Mechanical Properties of Waste Concrete Powder and Coconut Shell Ash," vol. 7, no. 11, pp. 10-14, 2019.

[5] A. . Awang-Hazmi, M. Z. A. Bakar, J. Abu, and M. M. Noordin, "Mineral composition of the cockle (Anadara granosa) shells of West Coast of Peninsular Malaysia and it's potential as biomaterial for use in bone repair," UPM institutional Repos., vol. 6, no. 5, pp. 591-594, 2007.

[6] S. F. S. Mohamad, S. Mohamad, and Z. Jemaat, "Study of calcinations condition on decomposition of calcium carbonate in waste cockle shell to calcium oxide using thermal gravimetric analysis," ARPN J. Eng. Appl. Sci., vol. 11, no. 16, pp. 9917-9921, 2016.

[7] I. A. Teridi and K. A. Kamarudin, "Advanced Research in Natural Fibers Behavior of Composite Cockle Shell and Kenaf Plate under Low Velocity Impact Test," vol. 1, no. 1, pp. 1-4, 2019.

[8] K. Muthusamy and N. A. Sabri, "Cockle Shell: A Potential Partial Coarse Aggregate Replacement in Concrete," vol. 1, no. 4, pp. 260-267, 2012.

[9] F. Sahari, "Cockle Shell As An Alternative Construction Material For Artificial Reef," no. September 2011, 2018.

[10] Y. Li, C. Zhao, H. Chen, L. Duan, and X. Chen, "CO 2 Capture Behavior of Shell during Calcination / Carbonation Cycles," no. 8, pp. 1176-1182, 2009. https://doi.org/10.1002/ceat.200900008

[11] H. Bharatham, M. Z. A. B. Zakaria, E. K. Perimal, L. M. Yusof, and M. Hamid, "Mineral and Physiochemical Evaluation of Cockle Shell ( Anadara granosa ) and Other Selected Molluscan Shell as Potential Biomaterials," vol. 43, no. 7, pp. 1023-1029, 2014.

[12] P. O. Sjoblom, J. T. Hartness, and T. M. Cordell, “On Low-Velocity Impact Testing of Composite Materials," J. Compos. Mater., vol. 22, no. 1, pp. 
30-52, 1988.

[13] C. S. Ho, M.K.N. Nor, N. Ma'at, K.Y.A. Sim, M.N Ibrahim, M.A Lajis and N.K Yusuf, "Damage Initiation and Evolution Analysis of Hot Extruded Recycled Aluminium Alloys (AA6061)," 10th Int. Conf. Mech. Manuf. Eng., pp. 1-8, 2019.

[14] S. Patil, D. M. Reddy, and M. Reddy, "Low velocity impact analysis on composite structures - A review," AIP Conf. Proc., vol. 1943, no. October, 2018.

https://doi.org/10.1063/1.5029585

[15] D. G. R. William D. Callister, Fundamentals of Materials Science and Engineering: An Integrated Approach pp180. 2009.

[16] N. K. Naik and A. V. Doshi, "Ballistic impact behaviour of thick composites: Parametric studies," Compos. Struct., vol. 82, no. 3, pp. 447-464, 2008.

[17] C. Akin and M. Şenel, "Experimental Study of Low Velocity Impact Response for Composite Laminated Plates," dumlupınar Üniversitesi Fe Bilim. Enstitüsü Derg., vol. 21, pp. 77-90, 2010.

[18] M. O. W. Richardson and M. J. Wisheart, "Review of low-velocity impact properties of composite materials," Compos. Part A Appl. Sci. Manuf., vol. 27, no. 12 PART A, pp. 1123-1131, 1996. https://doi.org/10.1016/1359-835X(96)00074-7

[19] S. Safri, M. Sultan, N. Yidris, and F. Mustapha, "Low Velocity and High Velocity Impact Test on Composite Materials-A review," Int. J. Eng. Sci, no. January, pp. 50-60, 2014.

[20] L. . Hollaway and P. . Head, Advance Polymer Composite and Polymers in The Civil Infrastructure. Elsevier, 1985.

[21] A. K. Kareem, A. E. Ismail, S. Jamian, and M. N. Nemah, "Influence Coefficients for a single superficial cracked thick cylinder under torsion and bending moments," vol. 4, pp. 132-144, 2020.

[22] S. P. Joshi and C. T. Sun, "Impact Induced Fracture in a Laminated Composite," J. Compos. Mater., vol. 19 , no. 1, pp. 51-66, 1985. https://doi.org/10.1177/002199838501900104

[23] K. A. Kamarudin, M. Iqbal, H. Roslan, S. Jamian, and I. A. Hamid, "Mechanical Properties of Seashell Structure Under Different Drying Temperature," vol. 3, no. 1, pp. 1-4, 2019. 